(c) American Dairy Science Association, 2005.

\title{
Processing Whole Cottonseed Moderates Fatty Acid Metabolism and Improves Performance by Dairy Cows*
}

\author{
C. Reveneau, C. V. D. M. Ribeiro, M. L. Eastridge, N. R. St-Pierre, and J. L. Firkins* \\ Department of Animal Sciences, The Ohio State University, Columbus 43210
}

\begin{abstract}
Pelleting cottonseed (CS) improves handling characteristics. Our objectives were to determine whether increasing the particle size of the CS pellet or dilution of a smaller pellet with delinted CS would limit the rate of CS oil release to optimize digestibility of fatty acids (FA) and fiber while maintaining milk fat production. In a $5 \times 5$ Latin square design with 3 -wk periods, 5 rumen-cannulated cows were fed 1) control with CS hulls $(\mathrm{CSH})$ and $\mathrm{CS}$ meal plus tallow and Ca soaps of FA, 2) whole CS (WCS), 3) small CS pellets (SP; 0.44cm die diameter), 4) larger CS pellets (LP; 0.52-cm die diameter), or 5 ) a blend of $1 / 2$ SP plus $1 / 2$ partially delinted CS (SPD). Diets contained $39.6 \%$ concentrate, $14.4 \%$ $\mathrm{CS}$, and $46 \%$ forage (40:60, alfalfa hay:corn silage) on a DM basis and were balanced to have similar concentrations of CS protein, CS fiber, and total fat. In a production trial, dietary treatments were 1) WCS control, 2) LP, 3) SPD, and 4) SPD fed at 90\%. Sixty cows averaging $105 \mathrm{~d}$ in milk were fed the WCS diet for 2 wk and then assigned to one of the 4 diets for $12 \mathrm{wk}$. Total tract digestibility of NDF was unaffected, but N digestibility was lower for SPD than for other treatments. Fatty acid digestibility was higher for SP and LP (82.6 and 82.3\%) than for CSH or SPD treatments (78.8 and $75.3 \%)$, and WCS was intermediate $(81.1 \%)$. The trans- $11 \mathrm{C}_{18: 1}$ from cows fed SP and LP (6.58 and $6.24 \%$ of total milk FA) was greater than that from cows fed CSH, WCS, and SPD (3.23, 3.79, and 3.97\%). The trans- $10 \mathrm{C}_{18: 1}$ in milk fat from SP and LP $(0.508$ and $0.511 \%$ ) was higher than that in WCS and SPD diets $(0.316$ and $0.295 \%)$; $\mathrm{CSH}$ was intermediate $(0.429 \%)$. Using passage rates estimated from the NRC, disappearance of total FA in situ was estimated to be 17.7, 44.2, 46.6, and $35.0 \%$ for WCS, SP, LP, and SPD, respectively. In the production trial, a diet $\times$ week interaction was explained by a trend for progressively
\end{abstract}

Received June 15, 2005.

Accepted August 22, 2005.

Corresponding author: J. L. Firkins; e-mail: firkins.1@osu.edu.

*Salaries and research support were provided by state and federal funds appropriated to the Ohio Agricultural Research and Development Center, The Ohio State University. Manuscript No. 15-05AS. greater milk production for SPD and SPD90 than for WCS or LP. Milk fat was lower for LP $(2.74 \%)$ and SPD90 (2.85\%) than for WCS or SPD (3.07 and 3.08\%). The fat yield was lower for LP than for SPD (1.09 and $1.30 \mathrm{~kg} / \mathrm{d})$; WCS and SPD90 were intermediate (1.23 and $1.21 \mathrm{~kg} / \mathrm{d}$ ). Although having a lower FA digestibility, SPD appeared to minimize negative effects of free oil from SP in the rumen, explaining higher DMI and milk production compared with WCS or LP.

(Key words: pelleted cottonseed, dairy cow, in situ, milk fatty acid)

Abbreviation key: $\mathbf{C S}=$ cottonseed, $\mathbf{C S H}=$ cottonseed hulls, ERD = effective ruminal disappearance, FA = fatty acids, $\mathbf{L P}=$ large CS pellets, $\mathbf{S P}=$ small CS pellets, SPD $=1 / 2$ SP plus $1 / 2$ partically delinted CS, SPD90 = SPD fed at $90 \%, \mathbf{W C S}=$ whole CS.

\section{INTRODUCTION}

The high $\mathrm{NE}_{\mathrm{L}}$ concentration of whole linted cottonseed (WCS) combined with its balanced nutrient composition makes it a valuable commodity for high-producing dairy cows (Bernard and Calhoun, 1997). With high levels of effective NDF, CP, and fatty acids (FA), WCS serves concurrently as a forage replacer and a concentrate (Harvatine et al., 2002a). Nonetheless, the physical characteristics of WCS lead to storage and handling difficulties in some feeding situations. As reviewed by Arieli (1998), various processing methods have been developed to overcome these inconveniences, and pelleting of WCS greatly improves its handling characteristics. Pelleted WCS offer the same nutritional benefits as WCS for NDF effectiveness (Lima et al., 2003) and for CP (Bernard and Amos, 1985; Meyer et al., 2001). However, the crushing of the WCS during the pelleting process frees the seed oil; this oil is rich in linoleic and other unsaturated FA, which are implicated to adversely impact ruminal fermentation and milk production (Chouinard et al., 2001). Diets rich in linoleic acid often increase the formation of trans FA in the rumen, which can decrease de novo FA synthesis in the mammary gland (Chouinard et al., 2001; Bauman and Griinari, 2003). 
Another method to improve handling is by partially delinting the cottonseed (CS). Diets supplemented with Pima CS, a naturally delinted variety with potentially different nutritional properties than conventional CS, had lower ether extract digestibility compared with diets with cracked seeds (Sullivan et al., 1993). The percentage of consumed seeds recovered in feces was higher with Pima (Sullivan et al., 1993) and tended to be higher for delinted CS (Moreira et al., 2004), which might indicate lower fat digestibility. Recently, Solomon et al. (2005) discussed the possibility that lower ether extract digestibility for Pima seeds might result from passage of intact fragments of seeds or from ruminal escape of triglycerides that might be more poorly absorbed than FA. Therefore, it is not known if FA digestibility of delinted CS would be lower than that of WCS. Although dairy cows fed delinted CS or WCS had similar lactation performance (Moreira et al., 2004), pelleting CS could improve fat digestibility compared with WCS or delinted CS.

In the present study, we surmised that pelleting CS would increase the rate of oil being released from the seed and thus be detrimental to ruminal processes. We hypothesized that other processing methods, such as larger CS pellets (LP) or the mixing of conventional small CS pellets (SP) in equal parts with partially delinted WCS (SPD), would moderate the free oil availability and avoid the detrimental effects to ruminal fermentation. Furthermore, the SP in the SPD treatment were projected to increase FA digestibility compared with delinted CS, but the latter were expected to be more inert in the rumen than SP. Therefore, both components were hypothesized to provide positive associative effects. Moreira et al. (2004) suggested that 0.95 parts of delinted CS were equivalent to 1.0 part of WCS, based on increased concentration of CS fat by delinting. Combining the potential positive associative effects of SP and delinted CS plus the increasing fat concentration of delinted CS, 90\% SPD plus 10\% more concentrate was hypothesized to be equivalent to $100 \%$ WCS. Our objectives were to determine effects of CS treatments on ruminal fat inertness and fiber disappearance in situ, total tract digestibility of nutrients, and milk FA composition in a digestibility trial followed by a production trial to evaluate overall efficacy of CS treatments for mid-lactation dairy cows.

\section{MATERIALS AND METHODS}

\section{Experiment 1: Digestibility Trial}

Animals and diets. Five multiparous Holstein cows were fitted with rumen cannulas as per approved animal care and use guidelines. At the start of the experiment, cows were 49,61, 126, 132, and 163 DIM. All 5 cows received each of the diets in five 21-d periods in a $5 \times 5$ Latin square design.

The 5 diets were formulated to have $46 \%$ forage, which consisted of alfalfa hay:corn silage (40:60 DM basis) to provide $18 \%$ forage NDF. The diets were fed as TMR with alfalfa hay chopped prior to mixing (Table 1). Three replicate composited samples of TMR were placed on a bank of 6 sieves (pore sizes of 9.5, 4.75, $2.36,1.18,0.6,0.45 \mathrm{~mm}$ ) and separated on an oscillating sieve shaker for $10 \mathrm{~min}$. Geometric mean diameter (based on a log-normal distribution) were 4.9, 6.3, 5.6, 5.4, 5.4, and 5.2 for CSH, WCS, LP, SP, SPD, and SPD90, respectively. Distributions of particles, as a percentage of total DM, on the 6 screens in descending order of pore size and the pan, respectively, were CSH: 15.1, 36.8, 25.9, 12.1, 6.7, 2.6, 0.7; WCS: 23.7, 44.9, 14.4, 8.5, 5.3, 2.3; LP: 16.4, 44.6, 17.9, 10.2, 6.8, 3.6, 0.5; SP: 10.7, 49.6, 16.9, 11.9, 7.1, 2.9, 0.8; SPD: 9.5, 53.7, 17.5, 10.0, 6.0, 2.6, 0.7; and SPD90: 11.0, 45.1, 18.8, 12.3, 7.9, 3.9, 1.0 .

The 5 diets consisted of a control diet plus 4 dietary treatments including CS products at $14.4 \%$ of DM. Assuming $75 \%$ NDF effectiveness from CS products (Harvatine et al., 2002b), the diets were consistent with the current NRC (2001) recommendations for minimum fiber in dairy rations (21\% effective NDF). Diets were balanced to be equivalent in nutrient composition on a $\mathrm{DM}$ basis (30\% NDF, $5.5 \%$ lipid, $18 \% \mathrm{CP}$, and $12 \%$ RDP). To isolate the effect of CS oil, the control diet was formulated to be similar in $\mathrm{NE}_{\mathrm{L}}$ and protein by substituting CS products with CS hulls and meal as a source of fiber and protein. The fat from CS products was substituted by a combination of $35 \%$ tallow and 65\% Megalac (Church \& Dwight Co., Princeton, NJ) as a control to provide the same level of FA but which, based on conventional feeding practices, was expected to be inert enough in the rumen to not depress milk fat percentage. This diet was designated as whole linted CS hulls (CSH). The four other dietary treatments were WCS as a positive control, SP, LP, and SPD. The SP and mechanically delinted CS are marketed as FuzZPellets and CottonFlo, respectively (Buckeye Technologies, Memphis, TN); the SP and SPD products were provided by the manufacturer. Diets were prepared once daily as a TMR and fed twice daily in equal proportions at 0700 and $1900 \mathrm{~h}$. The corn silage DM was measured weekly for ration adjustment. Orts were weighed daily at $1700 \mathrm{~h}$ to adjust feed offered for $5 \%$ refusal.

Experimental periods consisted of $21 \mathrm{~d}$; $\mathrm{d} 1$ through 14 served as an adjustment period, and d 15 to 21 were for data collection. Cows were injected with Posilac (Monsanto, St. Louis, MO) 2 wk before the initiation and every 2 wk throughout the trial. Cows were weighed prior to the p.m. milking on d 7, 14, and 21 of 
each period; BW was averaged per period. The BCS (1 to 5 scale; NRC, 2001) of each cow were recorded at d 2 and 16 of each period. Feed offered and individual dietary components were sampled on d 14 through 17 , and orts were sampled on d 15 through 18. Samples were composited by cow, sample type, and period and were frozen at $-20^{\circ} \mathrm{C}$. A composite of each sample was dried at $60^{\circ} \mathrm{C}$ and ground in a Wiley mill (Arthur $\mathrm{H}$. Thomas, Philadelphia, PA) through a 2-mm screen prior to nutrient analyses.

Ruminal metabolism. Core samples (approximately $500 \mathrm{ml}$ ) of ruminal contents from 8 different sites in the rumen were removed at $3,6,9$, and $12 \mathrm{~h}$ after the a.m. feeding on $\mathrm{d} 15$ of each period (Harvatine et al., 2002a). Contents were strained through 2 layers of cheesecloth, and $\mathrm{pH}$ of the fluid was measured immediately. A 47-mL aliquot of the filtered ruminal fluid was acidified with $3 \mathrm{~mL}$ of $6 \mathrm{~N} \mathrm{HCl}$ to stop fermentation and frozen. After thawing, the acidified ruminal fluid was mixed, centrifuged at $15,000 \times g$ at $4^{\circ} \mathrm{C}$ for $15 \mathrm{~min}$, and then filtered through Whatman number 1 filter paper (Whatman, Clifton, NJ). The supernatant was analyzed for VFA concentrations by GLC (Harvatine et al., 2002a).

Disappearance of alfalfa hay NDF and CS products in situ. Alfalfa hay and the respective CS products were incubated in situ in the rumen of the cow fed the corresponding diet during each period. The CS products were incubated in their native forms with the exception of WCS and SPD, which were cracked through a roller beforehand to mimic initial mastication. This processing of the samples seemed to be the most appropriate to evaluate the effect of the release of oil in the various CS products. The alfalfa hay was ground in a Wiley mill through a 2-mm screen. Approximately $2 \mathrm{~g}$ of DM of ground alfalfa hay or CS products were placed into polyester bags $(10 \mathrm{~cm} \times 20 \mathrm{~cm}$; Ankom Technology Corp., Macedon, NY) with a mean pore size of $50 \mu \mathrm{m}$. Before use, the bags were dried in a forced-air oven at $55^{\circ} \mathrm{C}$ for $48 \mathrm{~h}$ for taring. Filled bags were heat-sealed $2 \mathrm{~cm}$ below the top. Bags were placed into a laundry bag and incubated for $0,2,4,8,12,24,48$, and $96 \mathrm{~h}$. After removal, the bags were washed until the rinse water was completely clear and were frozen at $-20^{\circ} \mathrm{C}$ until lyophilization.

The ground alfalfa hay and CS products were analyzed for NDF using an Ankom A200 analyzer (Ankom). Half-gram samples were thermally sealed in filter bags and presoaked in acetone to prevent interference of FA with the detergent solution. The samples were refluxed for $75 \mathrm{~min}$ in the presence of heat-stable amylase (Sigma A3306, Sigma Chemical Co., St. Louis, MO) and then rinsed with 2 applications of $2 \mathrm{~L}$ of hot distilled water containing heat-stable amylase. Excess moisture was removed by soaking the samples in acetone; the final moisture was removed using a drying oven. The CS products and their in situ residues were analyzed for Kjeldahl N (AOAC, 1990).

Fatty acid analysis was conducted with one of the procedures reviewed by Palmquist and Jenkins (2003). The FA were first methylated with $5 \mathrm{~mL}$ of $10 \%$ methanolic $\mathrm{HCl}\left(2 \mathrm{~h}\right.$ at $\left.90^{\circ} \mathrm{C}\right)$. Nonadecanoic acid (19:0) was used as internal standard. After addition of $1 \mathrm{~mL}$ of hexane and $10 \mathrm{~mL}$ of $6 \% \mathrm{~K}_{2} \mathrm{CO}_{3}$, the samples were centrifuged for $5 \mathrm{~min}$ at $500 \times \mathrm{g}$ to separate solvent layers. The organic layer was transferred to a $13-\times$ $100-\mathrm{mm}$ culture tube containing $1 \mathrm{~g}$ each of sodium sulfate and charcoal, capped with a Teflon-lined screw cap, and centrifuged. The samples were then transferred into 1-mL GLC auto sampler vials, capped, and stored at $-20^{\circ} \mathrm{C}$ until GLC analysis. Retention times and response factors were determined with methyl ester standards purchased from Nu-Check Prep (Elysian, MN; GLC-60, UC-50M) and Matreya, Inc. (Pleasant Gap, PA; FIM-FAME-7).

Fatty acid methyl esters were separated by using a HP 5890 Series II gas chromatograph (Hewlett Packard Co., Palo Alto, CA) equipped with a fused silica capillary column (SP-2380; 100-m length, 0.25-mm id, and 0.2$\mathrm{mm}$ film thickness; Supelco Inc., Bellefonte, PA). Methyl esters were then quantified with the ChemStation software (Agilent Technologies, Wilmington, DE). Helium was used as the carrier gas. Injector and flame ionization detector temperatures were set at 223 and $260^{\circ} \mathrm{C}$, respectively, and the split ratio was set at 80:1. Oven temperature was set for $140^{\circ} \mathrm{C}$, held for $5 \mathrm{~min}$, then increased by $4^{\circ} \mathrm{C} / \mathrm{min}$ to $240^{\circ} \mathrm{C}$, held for $15 \mathrm{~min}$, decreased by $20^{\circ} \mathrm{C} / \mathrm{min}$ to $140^{\circ} \mathrm{C}$, and held for $0.5 \mathrm{~min}$.

For a given nutrient (NDF, CP, and FA), the percentage of original nutrient disappearing over time of incubation was fitted for each series of data using the Marquardt option of the NLIN procedure from SAS (v9.1, SAS Inst., Inc., Cary, NC): $\mathrm{y}=\mathrm{A}+\mathrm{B} \times\left(1-\mathrm{e}^{-\mathrm{kd} \times(\mathrm{t}-\mathrm{L})}\right)$, where $\mathrm{A}=$ the soluble fraction washing out at $0 \mathrm{~h}(\%)$, $\mathrm{B}=$ insoluble potentially degradable fraction $(\%), \mathrm{k}_{\mathrm{d}}=$ fractional degradation rate $(/ \mathrm{h}), \mathrm{t}=$ time $(\mathrm{h})$, and $\mathrm{L}=$ lag time (h). Because L was not significantly different from zero, it was removed from all subsequent models. When no inflection in the time-course was fit (i.e., C = 0 ), which occurred only for WCS, bounds were set for A and B such that their sum would not exceed disappearance at $96 \mathrm{~h}$ for a given incubation. The indigestible (C) fraction was solved as $100 \%-(\mathrm{A}+\mathrm{B})$. The effective ruminal disappearance (ERD) was estimated as ERD = $A+B\left[k_{d} /\left(k_{d}+k_{p}\right)\right]$, where A, B, and $k_{d}$ are the degradation parameters described previously, and $\mathrm{k}_{\mathrm{p}}$ is the rate of passage, which was calculated using NRC (2001) as $\mathrm{k}_{\mathrm{p}}(\% / \mathrm{h})=3.362+0.479 \times(\mathrm{DMI}, \%$ of BW $)-0.017 \times$ 
Table 1. Ingredient and chemical composition of experimental diets for experiments 1 and $2 .{ }^{1}$

\begin{tabular}{|c|c|c|c|c|c|c|}
\hline & $\mathrm{CSH}$ & WCS & SP & LP & SPD & SPD90 \\
\hline & & & $\longrightarrow($ & M) - & & \\
\hline \multicolumn{7}{|l|}{ Ingredient } \\
\hline Alfalfa hay, chopped & 18.3 & 18.3 & 18.3 & 18.3 & 18.3 & 18.3 \\
\hline Corn silage & 27.4 & 27.4 & 27.4 & 27.4 & 27.4 & 27.4 \\
\hline CSH & 7.2 & - & - & - & - & - \\
\hline WCS & - & 14.4 & - & - & - & - \\
\hline SP & - & - & 14.4 & - & - & - \\
\hline LP & - & - & - & 14.4 & - & - \\
\hline SPD & - & - & - & - & 14.4 & 13.0 \\
\hline Corn, ground shelled & 24.6 & 26.5 & 26.5 & 26.5 & 26.5 & 27.4 \\
\hline Soybean meal, $48 \% \mathrm{CP}$ & 10.6 & 11.3 & 11.3 & 11.3 & 11.3 & 11.7 \\
\hline Urea & 0.22 & 0.22 & 0.22 & 0.22 & 0.22 & 0.23 \\
\hline Dicalcium phosphate & 0.26 & 0.22 & 0.22 & 0.22 & 0.22 & 0.23 \\
\hline Limestone & 0.50 & 0.98 & 0.98 & 0.98 & 0.98 & 1.01 \\
\hline Magnesium oxide & 0.16 & 0.11 & 0.11 & 0.11 & 0.11 & 0.12 \\
\hline Trace-mineralized salt ${ }^{2}$ & 0.50 & 0.50 & 0.50 & 0.50 & 0.50 & 0.52 \\
\hline Vitamin premixes ${ }^{3}$ & 0.12 & 0.12 & 0.12 & 0.12 & 0.12 & 0.12 \\
\hline Cottonseed meal & 5.64 & - & - & - & - & - \\
\hline Megalac $^{4}$ & 2.02 & - & - & - & - & - \\
\hline Soybean hulls & 1.42 & - & - & - & - & - \\
\hline Tallow & 1.06 & - & - & - & - & - \\
\hline \multicolumn{7}{|l|}{ Chemical analysis } \\
\hline $\mathrm{DM}, \%$ & 59.7 & 60.0 & 61.0 & 60.6 & 60.7 & 59.5 \\
\hline $\mathrm{NDF}$ & 31.5 & 32.2 & 29.4 & 32.2 & 31.6 & 31.5 \\
\hline Forage NDF & 18.6 & 18.6 & 18.6 & 18.6 & 18.6 & 18.6 \\
\hline $\mathrm{ADF}$ & 20.2 & 19.6 & 18.2 & 19.6 & 20.4 & 18.6 \\
\hline $\mathrm{ADL}^{5}$ & 6.0 & 4.8 & 5.0 & 4.8 & 4.9 & 5.5 \\
\hline $\mathrm{CP}$ & 18.6 & 17.6 & 18.5 & 17.6 & 17.2 & 17.6 \\
\hline NDIN $^{6}$ & 0.2 & 0.2 & 0.2 & 0.2 & 0.2 & 0.2 \\
\hline Ash & 7.3 & 6.8 & 7.2 & 6.9 & 6.7 & 6.7 \\
\hline Fatty acids & 5.3 & 6.2 & 6.1 & 5.8 & 5.8 & 6.0 \\
\hline $\mathrm{NFC}^{7}$ & 36.1 & 33.3 & 37.5 & 40.7 & 40.7 & 39.5 \\
\hline \multirow[t]{2}{*}{$\mathrm{NE}_{\mathrm{L}},{ }^{8} \mathrm{Mcal} / \mathrm{kg}$ of $\mathrm{DM}$} & 1.64 & 1.65 & 1.66 & 1.63 & 1.63 & 1.63 \\
\hline \multirow{2}{*}{\multicolumn{7}{|c|}{ Fatty acid profile }} \\
\hline & & & & & & \\
\hline $\mathrm{C}_{16: 0}$ & 32.1 & 22.4 & 21.7 & 21.6 & 21.5 & 21.5 \\
\hline $\mathrm{C}_{18: 0}$ & 6.1 & 2.0 & 2.1 & 2.1 & 2.1 & 2.1 \\
\hline cis-9 $\mathrm{C}_{18: 1}$ & 28.4 & 13.0 & 13.7 & 13.6 & 13.4 & 13.4 \\
\hline cis-9, cis-12 $\mathrm{C}_{18: 2}$ & 19.8 & 52.3 & 53.1 & 52.9 & 53.3 & 53.3 \\
\hline $\mathrm{C}_{18: 3}$ & 0.52 & 0.29 & 0.28 & 0.28 & 0.27 & 0.27 \\
\hline
\end{tabular}

${ }^{1} \mathrm{CSH}=$ whole linted cottonseed hulls, WCS = whole linted cottonseed, SP = conventional small WCS pellets, LP = larger pelleted WCS, SPD = combination of WCS products (small WCS pellets and partially delinted WCS product mixed in equal parts), and SPD90 = SPD at 90\% of the SPD level. When diets are in common (WCS, LP, and SPD) for both experiments, only the chemical composition of experiment 2 is shown.

${ }^{2}$ Contained $0.10 \% \mathrm{Mg}, 38.0 \% \mathrm{Na}, 58.0 \% \mathrm{Cl}, 0.04 \% \mathrm{~S}$, and $5000 \mathrm{mg}$ of $\mathrm{Fe} / \mathrm{kg}, 7500 \mathrm{mg}$ of ZN/kg, $2500 \mathrm{mg}$ of $\mathrm{Cu} / \mathrm{kg}, 6000 \mathrm{mg}$ of $\mathrm{Mn} / \mathrm{kg}, 100 \mathrm{mg}$ of $\mathrm{I} / \mathrm{kg}, 60 \mathrm{mg}$ of Se/kg, and $50 \mathrm{mg}$ of Co/kg.

${ }^{3}$ Supplied approximately $134 \mathrm{kIU}$ of vitamin A, $27 \mathrm{kIU}$ of vitamin D, and $600 \mathrm{IU}$ of vitamin E per cow per day.

${ }^{4}$ Church \& Dwight, Princeton, NJ.

${ }^{5} \mathrm{ADL}=$ Acid detergent lignin.

${ }^{6} \mathrm{NDIN}=$ Neutral detergent insoluble nitrogen.

${ }^{7} \mathrm{NFC}=$ Nonfiber carbohydrates $[\mathrm{OM}-\mathrm{NDF}-\mathrm{CP}-(\mathrm{FA}+1)+(\mathrm{NDIN} \times 6.25)]$, where FA $=$ fatty acid.

${ }^{8}$ Calculated from NRC (2001).

$(\% \mathrm{NDF}, \mathrm{DM}$ basis $)-0.007 \times(\%$ concentrate in diet DM) derived from each animal's actual DMI and BW per period.

Total tract digestibility. Digestibility was measured on d 15 to 18 of each period (Harvatine et al., 2002a). A pellet (400 g/d) containing $5 \%$ chromic oxide and $95 \%$ soybean meal $(48 \% \mathrm{CP})$ was dosed through the rumen cannulas twice daily on $d 9$ through 18 . Fecal grab samples were taken on $d 15$ to 18 of each period so that every $2 \mathrm{~h}$ in a 12 -h period between feedings 
were represented ( 6 samples total). Samples were frozen during collection, dried in a forced-air oven at $55^{\circ} \mathrm{C}$ for $60 \mathrm{~h}$, and composited for each animal by equal sample weight at the end of each period. The chromic oxide pellets were composited by period and ground manually using a mortar and pestle.

The samples of feed offered, orts, fecal contents, and individual dietary components were ground to pass through a 2-mm screen (Wiley Mill, Arthur H. Thomas, Philadelphia, PA), and nutrients were analyzed for DM, OM, and N (AOAC, 1990). Chromic oxide pellets and fecal samples were analyzed for $\mathrm{Cr}$ by atomic absorption spectroscopy (Williams et al., 1962). The NDF and ADF concentrations of feed, orts, chromic oxide pellets, fecal samples, and feed lignin concentration were determined using the ANKOM filter bag method that was described previously. The total FA of dried feeds, orts, CS products, and fecal contents were analyzed, as just described.

Milk production and composition. Cows were housed in a conventional tie-stall barn with mattresses. Cows were milked at 0500 and $1700 \mathrm{~h}$ daily; milk yield was recorded at each milking. Four consecutive milk samples were taken at a.m. and p.m. milkings on $d 17$ to 19 of each period, and each sample was split into 2 aliquots. The first aliquot of the milk sample was stored at $4^{\circ} \mathrm{C}$ with a preservative and analyzed by DHI Cooperative Inc. (Columbus, $\mathrm{OH}$ ) for lactose, fat, true protein, and MUN (AOAC, 1990). Milk fat and protein yields were calculated per milking. Daily milk fat and protein percentages were weighted for the amount of milk per milking. All data were averaged per period prior to statistical analysis.

The second aliquot of milk was stored at $-20^{\circ} \mathrm{C}$ until it was analyzed for FA profile by GLC analysis. The frozen milk samples were rapidly thawed, about $20 \mathrm{~mL}$ were centrifuged at $12,000 \times g$ for $20 \mathrm{~min}$ at $4^{\circ} \mathrm{C}$, and then 300 to $350 \mathrm{mg}$ of fat cake were removed. First, the FA of milk were methylated in 2 steps with $2 \mathrm{~mL}$ of 0.5 $M$ sodium methoxide $\left(10 \mathrm{~min}\right.$ at $\left.50^{\circ} \mathrm{C}\right)$, followed by 3 $\mathrm{mL}$ of $5 \%$ methanolic $\mathrm{HCl}\left(10 \mathrm{~min}\right.$ at $\left.80^{\circ} \mathrm{C}\right)$ as described by Kramer et al. (1997). Then, the samples were processed as just described for in situ samples. The concentration and production of FA were then averaged per period.

Statistical analysis. Milk production and composition, milk FA profile, in situ degradation, and total tract digestibility data were analyzed as a $5 \times 5$ Latin square using PROC MIXED of SAS (v9.1, SAS Inst., Inc.) according to the following model: $\mathrm{Y}_{\mathrm{ijkl}}=\mu+\mathrm{T}_{\mathrm{i}}+\mathrm{P}_{\mathrm{j}}+\mathrm{c}_{\mathrm{k}}$ $+\mathrm{e}_{\mathrm{ijk} k}$, where $\mathrm{Y}_{\mathrm{ijkl}}=$ dependent variable, $\mu=$ overall mean, $\mathrm{T}_{\mathrm{i}}=$ fixed effect of treatment $\mathrm{i}(\mathrm{i}=1, \ldots, 5), \mathrm{P}_{\mathrm{j}}=$ fixed effect of period $\mathrm{j}(\mathrm{j}=1, \ldots, 5), \mathrm{c}_{\mathrm{k}}=$ random effect of cow $\mathrm{k}(\mathrm{k}=1, \ldots, 5) \sim \mathrm{N}\left(0, \sigma^{2}{ }_{\mathrm{c}}\right)$, and $\mathrm{e}_{\mathrm{ijk}}=$ random residual $\sim \mathrm{N}\left(0, \sigma^{2}{ }_{\mathrm{e}}\right) \cdot \mathrm{pH}$ and VFA concentrations were analyzed over time using the model described previously but with the addition of repeated measurements within cows by periods. The covariance structure that minimized the Akaike Information Criterion generally was the firstorder autoregressive structure. Significant differences were declared at $P<0.05$ unless otherwise stated. Fisher's protected least significant difference was used for mean separation.

\section{Experiment 2: Lactation Trial}

Animals and diets. A lactation trial was performed using 60 Holstein cows (32 primiparous, 28 multiparous) arranged in a randomized complete block design. The 4 diets were formulated as described for Experiment 1 (Table 1). Cows in their 16th week in milk received the WCS diet for a 2 -wk adaptation period, which also was used as a covariate period. Then, cows were blocked by week of calving as a random effect and randomly allotted within blocks to WCS, LP, SPD, or SPD90. Cows remained on the treatment diets for an additional $12 \mathrm{wk}$ after the adaptation period.

All cows were injected with Posilac starting on wk 16 of lactation and every $14 \mathrm{~d}$ thereafter. All housing and handling of cows were as described for experiment 1 , except for the following. The BW were measured weekly for each cow, and BCS were recorded at the start of the covariate period, at the treatment assignment, and every $3 \mathrm{wk}$ after that. The TMR was offered at $110 \%$ of ad libitum intake at 0600 and $1800 \mathrm{~h}$. A monthly composite of each weekly TMR sample was dried at $55^{\circ} \mathrm{C}$, and $\mathrm{DM}$ was measured at $105^{\circ} \mathrm{C}$. All feed analyses were performed as described previously.

Milk production and composition. Cows were milked at 0500 and $1700 \mathrm{~h}$ daily, with milk yield recorded at each milking. Milk samples were taken at 4 consecutive milkings each week, and each sample was analyzed for lactose, fat, true protein, and MUN. The milk components were weighted by milk volume and averaged by week per cow.

Statistical analysis. Weekly data for milk production were analyzed as a randomized complete block design using the MIXED procedure of SAS in which cows were blocked by week of entry on the trial. Variables from the adaptation period (averaged over wk 16 and 17 of lactation) were used as covariates. Repeated measures within cow (diet $\times$ parity) were analyzed using the covariate structure that minimized the Akaike information criterion, which was primarily compound symmetry or first-order autoregressive, with block as a random effect. The data were analyzed according to the following model: $\mathrm{Y}_{\mathrm{ijkl}}=\mu+\mathrm{D}_{\mathrm{i}}+\mathrm{P}_{\mathrm{j}}+\mathrm{W}_{\mathrm{k}}+\mathrm{DP}_{\mathrm{ij}}+$ $\mathrm{DW}_{\mathrm{ik}}+\mathrm{PW}_{\mathrm{jk}}+\mathrm{DPW}_{\mathrm{ijk}}+\mathrm{b}_{\mathrm{l}}+\mathrm{c}_{\mathrm{ijm}}+\mathrm{B}_{\mathrm{j}}\left(\mathrm{X}_{\mathrm{ijm}}-\bar{X}_{\mathrm{j}}\right)+\mathrm{e}_{\mathrm{ijk} \mathrm{l}}$, 
Table 2. Means for rumen fermentation characteristics for dairy cows fed different processed whole cottonseed products in experiment $1 .^{1}$

\begin{tabular}{lcccccl}
\hline & CSH & WCS & SP & LP & SPD & SEM \\
\hline $\mathrm{pH}$ & 6.17 & 6.15 & 6.12 & 6.14 & 6.14 & 0.09 \\
Total VFA, mM & 103 & 102 & 104 & 103 & 102 & 3 \\
VFA, mol/100 mol & & & & & \\
Acetate (A) & 60.2 & 59.9 & 59.1 & 59.7 & 59.7 & 1.1 \\
Propionate (P) & 26.2 & 26.6 & 26.8 & 26.4 & 26.6 & 1.2 \\
Butyrate & $9.91^{\mathrm{bc}}$ & $9.54^{\mathrm{c}}$ & $10.4^{\mathrm{a}}$ & $9.99^{\mathrm{b}}$ & $9.90^{\mathrm{bc}}$ & 0.31 \\
Isobutyrate & 0.79 & 0.80 & 0.71 & 0.79 & 0.73 & 0.06 \\
Valerate & 1.61 & 1.80 & 1.65 & 1.68 & 1.69 & 0.11 \\
Isovalerate & 1.31 & 1.37 & 1.34 & 1.41 & 1.36 & 0.08 \\
A:P & 2.42 & 2.33 & 2.24 & 2.32 & 2.31 & 0.15 \\
\hline
\end{tabular}

${ }^{\mathrm{a}, \mathrm{b}, \mathrm{c}}$ Means within a row with different superscripts differ $(P<0.05)$.

${ }^{1} \mathrm{CSH}=$ Whole linted cottonseed hulls, WCS $=$ whole linted cottonseed, $\mathrm{SP}=$ conventional small WCS pellets, $\mathrm{LP}=$ larger pelleted WCS, and SPD = combination of WCS products (small WCS pellets and partially delinted WCS product mixed in equal parts). Data are means of data from 3, 6, 9, and $12 \mathrm{~h}$ after feeding (treatment $\times$ time was $P>0.10$ ).

where $\mathrm{Y}_{\mathrm{ijk}} \mathrm{m}=$ dependent continuous variable; $\mu$ = overall mean; $D_{i}=$ fixed effect of diet $\mathrm{i}(\mathrm{i}=1, \ldots, 4) ; \mathrm{P}_{\mathrm{j}}=$ fixed effect of parity $\mathrm{j}(\mathrm{j}=1,2) ; \mathrm{W}_{\mathrm{k}}=$ fixed effect of week $\mathrm{k}$ $(\mathrm{k}=1, \ldots, 12)$ and its respective interactions $\mathrm{DP}_{\mathrm{ij}}, \mathrm{DW}_{\mathrm{ik}}$, $\mathrm{PW}_{\mathrm{jk}}$, and $\mathrm{DPW}_{\mathrm{ijk}} ; \mathrm{b}_{1}=$ random effect of block $\mathrm{l}(\mathrm{l}=$ $1, \ldots, 15) \sim \mathrm{N}\left(0, \sigma_{\mathrm{b}}^{2}\right) ; \mathrm{c}_{\mathrm{ijm}}=$ random effect of cow $\mathrm{m}$ within diet $\mathrm{i}$ and parity $\mathrm{j} \sim \mathrm{N}\left(0, \sigma_{\mathrm{c}}^{2}\right) ; \mathrm{B}_{\mathrm{j}}=$ regression coefficient (covariate) representing parity $\mathrm{j} ; \mathrm{X}_{\mathrm{ijm}}=$ covariate measurement for cow $\mathrm{m}$ within diet $\mathrm{i}$ and parity $\mathrm{j} ; \bar{X}_{\mathrm{j}}=$ mean covariate for parity $\mathrm{j}$; and $\mathrm{e}_{\mathrm{ijklm}}=$ residual error $\sim \mathrm{N}\left(0, \sigma_{\mathrm{e}}^{2}\right)$. When treatment $\times$ time interactions were significant $(P<0.05)$, treatment effects at each week were tested using the slice option from PROC MIXED. Covariate-adjusted least square weekly means were separated by Fisher's protected least-significant difference.

\section{RESULTS AND DISCUSSION}

\section{Experiment 1: Digestibility Trial}

Diets. All diets were similar in chemical composition compared with formulations (Table 1) and were accepted well by cows. The control diet (CSH), which was formulated with the same source of protein from CS meal and NDF from CSH, had a similar chemical composition to the WCS, SP, LP, and SPD diets, except for its FA content (a 2:1 blend of Megalac:tallow). Its supplemental FA were composed of $50 \%$ of 18 -carbon FA with equal proportions of $\mathrm{C}_{18: 1}$ and $\mathrm{C}_{18: 2}$, one third of $\mathrm{C}_{16: 0}$, and the residual $15 \%$ being short-, medium-, and other long-chain FA. The ruminal inertness of $\mathrm{Ca}$ salts of FA has been well studied (NRC, 2001).

The FA composition of the WCS, SP, LP, and SPD products was similar among treatments. Total 18-carbon FA represented almost $70 \%$ of the FA, with a pre- ponderance of $\mathrm{C}_{18: 2}$ (50\% of total $\mathrm{FA}$ ). The other $30 \%$ included nearly $22 \%$ of $\mathrm{C}_{16: 0}$ and $8 \%$ of short- and medium-chain FA (data not shown). Therefore, these similar FA profiles allowed us to test the effect of CS processing on the release of oil in the rumen on ruminal fermentation and milk production.

Ruminal fermentation. For rumen fermentation characteristics, no treatment $\times$ time interaction was significant $(P>0.10)$. Therefore, means for $\mathrm{pH}$ and VFA were averaged over all times (Table 2). The relative lack of difference among CS treatments on rumen $\mathrm{pH}$ or total VFA concentration is in accordance with previous studies with fats differing in saturation (Ohajuruka et al., 1991; Oldick and Firkins, 2000). Although we are aware of no studies evaluating kinetics of FA released from processed CS, Gonthier et al. (2004) demonstrated the protective effect of micronized flaxseeds, which are rich in $\mathrm{C}_{18: 2}$, from rumen degradation in Holstein cows. In particular, the flaxseed-processing treatment affected neither ruminal $\mathrm{pH}$ nor total VFA concentrations.

Whereas previous studies have reported a decrease in acetate:propionate with increasing unsaturation of the supplemented fat (Ohajuruka et al., 1991; Oldick and Firkins, 2000) or with processing of oilseed (Gonthier et al., 2004), we observed no significant differences in acetate or propionate concentrations or acetate:propionate with pelleting of CS. Sullivan et al. (2005) described a cubic pattern in total VFA concentration and a linear increase in acetate:propionate as free FA in WCS increased from 8 to $18 \%$ of total FA. Thus, apparently either the amount of free oil in SP or LP was not large enough or the lipolysis rate was not fast enough to build up concentrations of free FA to profoundly alter microbial processes in our study. As explained by Oldick and Firkins (2000), increasing frequency of feeding is 
Table 3. Least squares means of in situ disappearance kinetics from alfalfa hay or cottonseed products in experiment $1 .^{1}$

\begin{tabular}{|c|c|c|c|c|c|c|c|}
\hline Nutrient & Parameter $^{2}$ & $\mathrm{CSH}$ & WCS & SP & LP & SPD & SEM \\
\hline \multicolumn{8}{|l|}{ Alfalfa hay } \\
\hline \multirow[t]{6}{*}{$\mathrm{NDF}$} & Original, \% & 37.8 & 37.8 & 37.8 & 37.8 & 37.8 & - \\
\hline & $\mathrm{A}, \%$ & 9.7 & 6.5 & 8.9 & 6.1 & 7.7 & 1.2 \\
\hline & $\mathrm{B}, \%$ & 50.1 & 49.1 & 45.6 & 46.6 & 53.9 & 2.1 \\
\hline & C, $\%$ & 40.3 & 44.4 & 45.5 & 47.3 & 38.4 & 1.7 \\
\hline & $\mathrm{k}_{\mathrm{d}}, / \mathrm{h}$ & 0.0554 & 0.0515 & 0.0485 & 0.0599 & 0.0429 & 0.0063 \\
\hline & $\mathrm{ERD},{ }^{3} \%$ & 35.7 & 31.9 & 31.9 & 32.2 & 32.9 & 1.6 \\
\hline \multicolumn{8}{|l|}{ Cottonseeds } \\
\hline \multirow[t]{6}{*}{$\mathrm{NDF}$} & Original, \% & 89.5 & 55.0 & 56.7 & 54.6 & 53.7 & - \\
\hline & A, $\%$ & $4.24^{\mathrm{c}}$ & $4.45^{\mathrm{c}}$ & $24.7^{\mathrm{a}}$ & $20.6^{\mathrm{ab}}$ & $15.7^{\mathrm{b}}$ & 2.04 \\
\hline & $\mathrm{B}, \%$ & 43.5 & 44.8 & 39.3 & 44.6 & 42.4 & 6.4 \\
\hline & $\mathrm{C}, \%$ & 52.3 & 50.7 & 36.0 & 34.9 & 41.9 & 6.4 \\
\hline & $\mathrm{k}_{\mathrm{d}}, / \mathrm{h}$ & 0.0081 & 0.0157 & 0.0168 & 0.0125 & 0.0247 & 0.0061 \\
\hline & $\mathrm{ERD},{ }^{3} \%$ & $10.4^{\mathrm{d}}$ & $15.0^{\mathrm{c}}$ & $33.0^{\mathrm{a}}$ & $28.8^{\mathrm{b}}$ & $26.6^{\mathrm{b}}$ & 1.38 \\
\hline \multirow[t]{6}{*}{$\mathrm{CP}$} & Original, \% & - & 20.2 & 20.2 & 21.4 & 20.7 & - \\
\hline & A, $\%$ & - & $8.1^{\mathrm{d}}$ & $15.4^{\mathrm{bc}}$ & $25.2^{\mathrm{a}}$ & $18.6^{\mathrm{ab}}$ & 2.7 \\
\hline & $\mathrm{B}, \%$ & - & $76.9^{\mathrm{a}}$ & $62.2^{\mathrm{b}}$ & $54.1^{\mathrm{b}}$ & $66.9^{\mathrm{ab}}$ & 4.4 \\
\hline & $\mathrm{C}, \%$ & - & $15.1^{\mathrm{b}}$ & $22.3^{\mathrm{a}}$ & $20.7^{\mathrm{ab}}$ & $14.5^{\mathrm{b}}$ & 4.4 \\
\hline & $\mathrm{k}_{\mathrm{d}}, / \mathrm{h}$ & - & $0.0140^{\mathrm{b}}$ & $0.0743^{\mathrm{a}}$ & $0.1289^{\mathrm{a}}$ & $0.0311^{\mathrm{b}}$ & 0.0163 \\
\hline & $\mathrm{ERD},{ }^{3} \%$ & - & $21.0^{\mathrm{d}}$ & $48.0^{\mathrm{b}}$ & $59.4^{\mathrm{a}}$ & $38.5^{\mathrm{c}}$ & 1.8 \\
\hline \multirow[t]{6}{*}{ Fat } & Original, \% & - & 20.4 & 20.5 & 21.1 & 20.7 & - \\
\hline & $\mathrm{A}, \%$ & - & $7.6^{\mathrm{b}}$ & $19.5^{\mathrm{a}}$ & $26.9^{a}$ & $18.7^{\mathrm{a}}$ & 1.2 \\
\hline & $\mathrm{B}, \%$ & - & $81.9^{a}$ & $41.2^{\mathrm{b}}$ & $35.3^{\mathrm{b}}$ & $44.2^{\mathrm{b}}$ & 3.9 \\
\hline & C, \% & - & $10.5^{\mathrm{b}}$ & $39.3^{\mathrm{a}}$ & $37.8^{\mathrm{a}}$ & $37.0^{\mathrm{a}}$ & 4.1 \\
\hline & $\mathrm{k}_{\mathrm{d}}, / \mathrm{h}$ & - & $0.0066^{\mathrm{c}}$ & $0.0742^{\mathrm{a}}$ & $0.0574^{\mathrm{ab}}$ & $0.0298^{\mathrm{bc}}$ & 0.0119 \\
\hline & $\mathrm{ERD},{ }^{3} \%$ & - & $17.7^{\mathrm{c}}$ & $44.2^{\mathrm{a}}$ & $46.6^{\mathrm{a}}$ & $35.0^{\mathrm{b}}$ & 1.4 \\
\hline
\end{tabular}

a,b,c Means within a row with different superscripts differ $(P<0.05)$.

${ }^{1} \mathrm{CSH}=$ Whole linted cottonseed hulls, WCS $=$ whole linted cottonseed, SP = conventional small WCS pellets, LP = larger pelleted WCS, and SPD = combination of WCS products (small WCS pellets and partially delinted WCS product mixed in equal parts).

${ }^{2} \mathrm{~A}=$ Washout at time $0, \mathrm{~B}=$ potentially digestible fraction, $\mathrm{C}=$ indigestible fraction, and $\mathrm{k}_{\mathrm{d}}=$ degradation rate of the $\mathrm{B}$ pool. Original data in the feeds are shown, but statistics were not performed because these were not replicate samples. Data for $\mathrm{CP}$ and fat kinetics for $\mathrm{CSH}$ are not reported because of low concentrations: 7.2 and $2.3 \%$, respectively.

${ }^{3} \mathrm{ERD}$ is effective ruminal disappearance estimated as $\mathrm{ERD}=\mathrm{A}+\mathrm{B}\left[\left(\mathrm{k}_{\mathrm{d}} /\left(\mathrm{k}_{\mathrm{d}}+\mathrm{k}_{\mathrm{p}}\right)\right]\right.$. The passage rate $(\mathrm{kp})$ was calculated using NRC $(2001)$ as $\mathrm{kp}(\% / \mathrm{h})=3.362+0.479 \times(\mathrm{DMI}, \% \mathrm{BW})-0.017(\% \mathrm{NDF}$ in forage DM) -0.007 (\% concentrate in diet DM). The kp was divided by 100 for ERD.

another process of maintaining free FA below thresholds to inhibit NDF digestibility (Cant et al., 1990). Indeed, only molar percentage of butyrate was significantly different among treatments, with higher values in SP than WCS and intermediate values for LP, SPD, and $\mathrm{CSH}$. We have no explanation for the butyrate changes.

Disappearance of alfalfa hay NDF and CS products in situ. Because of low concentrations of $\mathrm{CP}$ and FA in CSH (7 and 3\%, respectively), the relative proportion of CP and FA from bacterial contamination (Perrier et al., 1992) was considered too high for these data to be meaningful, and data are not reported. As expected, based on fermentation characteristics, degradation of NDF of alfalfa hay in situ was not significantly different across diets (Table 3), resulting in a similar ERD between 31.9 and $35.7 \%$.

We found no differences in the potentially digestible fraction, the indigestible fraction, or the disappearance rate of NDF from CS products incubated in situ. However, the washout fraction was significantly different among diets, with values $>20 \%$ for SP and LP, intermediate for SPD (15.7\%), and $<5 \%$ for CSH and WCS. Pelleting methods for CS usually consist in crushing the seed, which reduces the particle size, as in soybean pelleting (Perrier et al., 1992). The washout rate was related to similar trends for ERD. The lower ERD for $\mathrm{CSH}$ and WCS might indicate that physical limitation of microbes to substrate could be lower than when those products are fed and masticated.

Many differences are noted for $\mathrm{N}$ kinetics of CS products (Table 3). The rolled WCS had lower washout, higher potentially digestible pools, and lower indigestible pools than SP, but the much slower disappearance rate caused ERD to be less than one-half that of SP (Table 3). Compared with SP, the LP had a higher washout pool and numerically faster disappearance rate, explaining the higher ERD for LP. Apparently, pelleting 

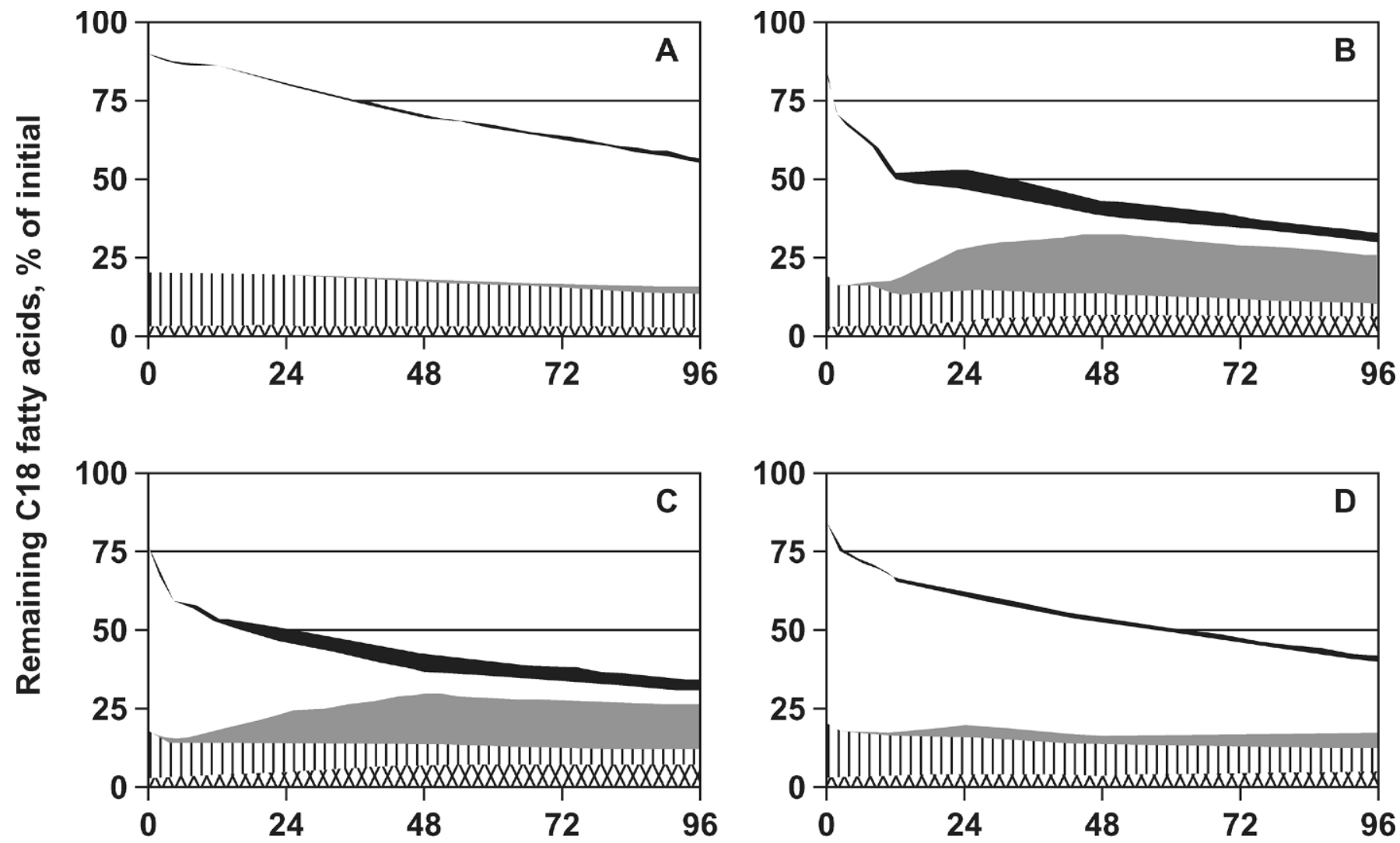

Time, h

Figure 1. Percentage of original C18 fatty acid isomers from whole cottonseed (WCS) products remaining in situ in experiment 1. A) WCS; B) small WCS pellets (SP); C) larger WCS pellets (LP); and D) combination of WCS products (SP and partially delinted WCS product mixed in equal parts; SPD). C18:0, cross-hatched pattern; C18:1 cis-9, vertical bar pattern; total C18:1 trans, shaded pattern; C18:2 cis-9, cis-12, open pattern; and total conjugated linoleic acid isomers, solid pattern.

conditions were different for SP and LP, explaining differences in ERD. Compared with SP, the SPD had a lower indigestible pool; the much slower $\mathrm{k}_{\mathrm{d}}$ explains the much lower ERD for SPD compared with SP. The low C (indigestible) pools for WCS and SPD demonstrate that our rolling method prior to incubation in situ should have been sufficient for adequate microbial exposure to the feeds to simulate in vivo expectations.

For total FA, the SP treatments had a significantly greater washout, lower potentially digestible pool, and a greater indigestible pool compared with WCS (Table 3 ). However, the much faster rate of disappearance caused the ERD to be greater for SP than for WCS. The rate of disappearance for WCS was so slow that it was not different from zero. The LP data were similar to SP. The rate of disappearance and ERD of total FA for SPD were intermediate compared with WCS and SP.

The amounts of the $\mathrm{C}_{18} \mathrm{FA}$ remaining in the Dacron bags are presented as a cumulative plot in Figure 1. The fast disappearance rate of $\mathrm{C}_{18} \mathrm{FA}$ in $\mathrm{SP}$ and LP, especially of the cis-9, cis-12 isomer (linoleic acid), contrasts with its slower release from WCS and SPD. The residual fraction of $\mathrm{FA}$ for $\mathrm{SP}$ and $\mathrm{LP}$ was enriched with conjugated linoleic acids and trans $-\mathrm{C}_{18: 1}$ FA compared with WCS and SPD. Both conjugated linoleic acids and trans $-\mathrm{C}_{18: 1} \mathrm{FA}$ are intermediates of the biohydrogenation of linoleic acid to stearic acid (Mosley et al., 2002). Various research groups discussed the disappearance of FA from oilseeds. Enjalbert et al. (2003) reported that $90 \%$ of the $\mathrm{C}_{18}$ disappeared over $24 \mathrm{~h}$, and the rate of biohydrogenation from Canola seed increased with extrusion. Perrier et al. (1992) pointed out how the in situ disappearance of FA from crushed soybean was the combination of particles escaping through the bag pores and of true biohydrogenation; they reported a disappearance of $42 \%$ of 18 -carbon FA at $4 \mathrm{~h}$ of incubation. Agazzi et al. (2004) concluded that discrepancies in the profile of biohydrogenation intermediates demonstrated a decreased ability of in situ techniques to accurately reflect in vivo metabolism. In our study, biohy- 
drogenation intermediates accumulated much more than they were converted to $\mathrm{C}_{18: 0}$ (Figure 1). Harfoot et al. (1973) reported an irreversible inhibition of trans$\mathrm{C}_{18: 1}$ conversion to stearic acid when initial concentration of cis-9, cis- $12 \mathrm{C}_{18: 2}$ was $>1 \mathrm{mg} / \mathrm{mL}$. Various researchers have encountered accumulation of trans $-\mathrm{C}_{18: 1}$ attributable to such inhibition (Wu and Palmquist, 1991; Enjalbert et al., 2003). The group B bacteria required to complete the biohydrogenation process (Harfoot and Hazlewood, 1997) might be inhibited in situ because the FA are sequestered and kept concentrated ( $400 \mathrm{mg}$ of FA) in the bag rather than diffusing to feed particles. Thus, we are assuming that the rates observed might not reflect actual in vivo rates, but the in situ technique still allows us to isolate the effect of CS processing for relative comparison among treatments. For example, both the disappearance of total FA and appearance of biohydrogenation intermediates in situ were similar for SP and LP, which also had similar in vivo responses (see subsequent discussion). Moreover, WCS and SPD appeared to have decreased release of FA or accumulation of FA intermediates from biohydrogenation in situ, thus supporting our conclusion that these sources are less likely to modify ruminal microbial activity or to influence milk fat synthesis compared with LP or SP.

Apparent total tract digestibility. Digestibilities of OM and NDF were similar among treatments (Table 4). The N digestibility was lower for SPD compared with CSH. The digestibility of FA was higher for SP and LP than for CSH or SPD treatments; SP and LP were similar to WCS. The CSH diet had an intermediate fat digestibility, apparently because of the tallow, which would be expected to have about $80 \%$ of the true FA digestibility of Megalac or vegetable oils (NRC, 2001). This probably would also explain the lower digestibility of 18-carbon FA; digestibility of $\mathrm{C}_{18: 0}$ should be lower than that of $\mathrm{C}_{16: 0}$ in tallow (NRC, 2001). However, SPD had the lowest fat digestibility. Because this was even lower than WCS and the SP component of SPD should have a high digestibility, the partially delinted CS component of SPD must have had a lower fat digestibility than WCS. Diets supplemented with Pima CS had a lower ether extract digestibility when fed to dairy cows (Sullivan et al., 1993), and it seems likely that excretion of delinted seeds might explain the lower FA digestibility in the SPD treatment. Harvatine (200b) demonstrated how passage rate decreased when WCS increased in the diets. The discrepancy might be related to the presence of linters, but excretion rates of delinted CS are variable (Moreira et al., 2004), thus demonstrating that interactions between the rumen particulate mat and trapping of processed CS for rumination are difficult to explain.
Milk production and composition. Other than average BW, for which we have no explanation, there were no other differences in lactation performance (Table 5), as would be expected for a small number of animals fed these diets for relatively short periods. Peterson et al. (2002) clearly established that a period length of 3 wk was sufficient to precisely measure the changes in milk FA profile, although lactation performance did not differ. Therefore, in our study, we consider 3-wk periods sufficient to ascertain differences in milk FA profile among diets, even if milk fat percentage was not affected significantly by diet.

Milk fat-protein inversion (lower fat than protein) occurred for all diets except WCS, for which fat and protein percentages were similar. Tallow can depress milk fat percentage (Ohajuruka et al., 1991; Onetti et al., 2001), but we assumed that the levels fed in the CSH diet (which also had Megalac, a rumen-inert fat source) would be sufficiently low to prevent milk fat depression. Milk fat-protein inversion was noted when WCS and other fibrous by-products were added, but forage NDF was decreased to $<11 \%$ (Slater et al., 2000). In our study, forage NDF and NFC are in accordance with NRC (2001) recommendations and were not expected to promote milk fat depression. Therefore, the causes for the low milk fat percentage in our study are not clear but could be related to our use of chopped alfalfa hay rather than to alfalfa silage, which was used in many previous studies. Although cows were individually fed, chopped hay still could promote more sporadic consumption of the grain portion of the TMR (Leonardi et al., 2005), which might have enhanced effects of unsaturated fat on milk fat synthesis.

Milk fat percentage depends on a combination of supply of FA from the diet, mobilization of fat from adipose tissue, and mammary gland synthesis of FA primarily from acetate. Although there were many treatment differences in individual FA, which are presented for completeness, these differences can be summarized best as groups (Table 6). Concentrations of short- and mediumchain $\mathrm{FA}\left(\mathrm{C}_{4: 0}\right.$ to $\mathrm{C}_{15: 0}$, which primarily are synthesized in the mammary gland de novo) were lower with $\mathrm{CSH}$, SP, and LP diets compared with the WCS diet. The inhibition of de novo FA synthesis by feeding unsaturated FA, and especially trans $-\mathrm{C}_{18: 1}$ isomers, has been previously demonstrated (Piperova et al., 2004; Castaneda-Gutierrez et al., 2005). Palmitic acid and total 16-carbon FA were higher percentages of milk FA with the CSH diet compared with CS diets, probably because of the much higher proportion of $\mathrm{C}_{16: 0}$ from tallow and Megalac, although this FA also is produced by the mammary gland.

The individual 18-carbon FA (only from diet or adipose tissue) also were significantly different among diet, 
Table 4. Means of apparent nutrient digestibility for dairy cows fed different processed whole cottonseed products in experiment $1 .^{1}$

\begin{tabular}{lllllll}
\hline & CSH & WCS & SP & LP & SPD & SEM \\
\hline & & & & & & \\
\cline { 4 - 7 } OM & 75.2 & 77.5 & 76.9 & 75.9 & 74.2 & 1.2 \\
NDF & 56.0 & 60.8 & 57.0 & 58.0 & 54.3 & 2.5 \\
N & $81.5^{\mathrm{a}}$ & $84.3^{\mathrm{a}}$ & $81.6^{\mathrm{a}}$ & $82.1^{\mathrm{a}}$ & $78.2^{\mathrm{b}}$ & 1.2 \\
Total fatty acids & $78.8^{\mathrm{b}}$ & $81.1^{\mathrm{ab}}$ & $82.6^{\mathrm{a}}$ & $82.3^{\mathrm{a}}$ & $75.3^{\mathrm{c}}$ & 2.8 \\
C $_{16}$ fatty acids & $82.1^{\mathrm{a}}$ & $83.3^{\mathrm{a}}$ & $84.2^{\mathrm{a}}$ & $83.6^{\mathrm{a}}$ & $75.4^{\mathrm{b}}$ & 2.6 \\
C $_{18}$ fatty acids & $76.5^{\mathrm{b}}$ & $79.9^{\mathrm{a}}$ & $82.4^{\mathrm{a}}$ & $82.1^{\mathrm{a}}$ & $75.0^{\mathrm{b}}$ & 3.3 \\
\hline
\end{tabular}

${ }^{\mathrm{a}, \mathrm{b}, \mathrm{c}} \mathrm{Means}$ within a row with different superscripts differ $(P<0.05)$.

${ }^{1} \mathrm{CSH}=$ Whole linted cottonseed hulls, WCS $=$ whole linted cottonseed, $\mathrm{SP}=$ conventional small WCS pellets, LP = larger pelleted WCS, and SPD = combination of WCS products (small WCS pellets and partially delinted WCS product mixed in equal parts).

with the following grouping: trans-10 $\mathrm{C}_{18: 1}$; trans- 11 $\mathrm{C}_{18: 1} ;$ cis-9, cis- $12 \mathrm{C}_{18: 2}$; and trans-10, cis-12 $\mathrm{C}_{18: 2}$ were higher in SP and LP than in WCS and SPD. Cows fed CSH had significantly more cis-9 $\mathrm{C}_{18: 1}(21.4 \%)$ and less $\mathrm{C}_{18: 0}(9.6 \%)$ than those fed the other diets, probably because of the higher $\mathrm{C}_{18: 1}$ concentration in the $\mathrm{CSH}$ diet. The higher dietary $\mathrm{C}_{18: 1}$ also probably explains why the trans-10 isomer was a much higher percentage of total trans- $\mathrm{C}_{18: 1}$ for CSH (Mosley et al., 2002) because several isomers other than this one are intermediates of $\mathrm{C}_{18: 2}$ biohydrogenation (Harfoot et al., 1973). Previous work has established that the synthesis of milk FA is regulated, in part, by the amount of certain trans and conjugated linoleic acid isomers produced from ruminal microbes, particularly the trans-10 $\mathrm{C}_{18: 1}$ (Piperova et al., 2004) and trans-10, cis-12 $\mathrm{C}_{18: 2}$ (Baumgard et al., 2002; Peterson et al., 2003). The LP, SP, and CSH treatments had the highest proportions of trans $-10 \mathrm{C}_{18: 1}$ relative to total $\mathrm{C}_{18: 1 .}$. On the other hand, this isomer was quite low for cows fed SPD, and the data were comparable with WCS, suggesting that partially delinted WCS must have diluted the effect of the SP in the SPD product. From the previously discussed results, we would expect that the CSH, SP, and LP diets would be more likely to depress milk fat synthesis in longer-term studies because of greater accessibility of FA to modify biohydrogenation pathways toward production of trans10 isomers.

\section{Experiment 2: Lactation Trial}

Milk production and composition. Although DMI and milk production are averaged over the entire 12wk period in Table 7, the gradual spreading of responses explained the significant treatment $\times$ time interactions (Figures 2 and 3). Only for wk 6 and 10 were means for DMI significantly different (Figure 2); WCS trended to decrease DMI more than the SPD treatments. However, a trend for decreasing DMI for cows fed WCS seemed apparent for the second half of the trial. By the third week on the trial, milk production by cows fed LP was lower (or tended to be lower) than that for cows fed SPD or SPD90, and milk production by cows fed WCS was intermediate or lower than that for cows fed SPD or SPD90 (Figure 3). Thus, we suggest that the lower fat digestibility of SPD was compensated by increased DMI and milk production compared with WCS. Unsaturated fat can depress DMI (Firkins and Eas-

Table 5. Means of lactation performance by dairy cows fed different processed whole cottonseed products in experiment $1 .^{1}$

\begin{tabular}{lcccccc}
\hline & CSH & WCS & SP & LP & SPD & SEM \\
\hline DMI, kg/d & 22.2 & 23.8 & 23.1 & 22.6 & 22.8 & 1.8 \\
Milk production, kg/d & 42.7 & 40.5 & 40.9 & 39.9 & 40.6 & 2.6 \\
Milk fat, \% & 2.69 & 3.11 & 2.79 & 2.84 & 2.92 & 0.35 \\
Milk protein, \% & 2.96 & 3.09 & 3.08 & 3.12 & 3.12 & 0.08 \\
MUN, mg/dL & 14.6 & 14.8 & 15.2 & 16.3 & 16.2 & 0.7 \\
$3.5 \%$ FCM, kg/d & 32.8 & 36.5 & 32.9 & 33.2 & 34.8 & 5.7 \\
BCS & 2.87 & 2.95 & 2.87 & 2.99 & 2.91 & 0.19 \\
BW, kg & $647^{\mathrm{bc}}$ & $653^{\text {ab }}$ & $642^{\mathrm{c}}$ & $657^{\mathrm{a}}$ & $652^{\mathrm{ab}}$ & 25 \\
\hline
\end{tabular}

a,b,c Means within a row with different superscripts differ $(P<0.05)$.

${ }^{1} \mathrm{CSH}=$ Whole linted cottonseed hulls, WCS $=$ whole linted cottonseed, SP $=$ conventional small WCS pellets, LP = larger pelleted WCS, and SPD = combination of WCS products (small WCS pellets and partially delinted WCS product mixed in equal parts). 
Table 6. Least squares means of fatty acid composition of milk fat for dairy cows fed different processed whole cottonseed products in experiment $1 .^{1}$

\begin{tabular}{|c|c|c|c|c|c|c|}
\hline & $\mathrm{CSH}$ & WCS & $\mathrm{SP}$ & LP & SPD & SEM \\
\hline & & & $(\mathrm{g} / 100 \mathrm{~g}$ & nilk fat) & & 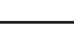 \\
\hline \multicolumn{7}{|l|}{ Fatty acid $^{2}$} \\
\hline $\mathrm{C}_{4: 0}$ & 2.91 & 2.91 & 2.59 & 2.67 & 2.89 & 0.15 \\
\hline $\mathrm{C}_{6: 0}$ & 1.56 & 1.78 & 1.53 & 1.54 & 1.76 & 0.15 \\
\hline $\mathrm{C}_{8: 0}$ & 0.824 & 1.007 & 0.873 & 0.852 & 0.997 & 0.107 \\
\hline $\mathrm{C}_{10: 0}^{0.0}$ & $1.78^{\mathrm{b}}$ & $2.30^{\mathrm{a}}$ & $2.05^{\mathrm{ab}}$ & $1.96^{\mathrm{b}}$ & $2.29^{\mathrm{a}}$ & 0.26 \\
\hline $\mathrm{C}_{12: 0}$ & $2.21^{\mathrm{b}}$ & $2.73^{\mathrm{a}}$ & $2.55^{\mathrm{a}}$ & $2.44^{\mathrm{b}}$ & $2.72^{\mathrm{a}}$ & 0.24 \\
\hline $\mathrm{C}_{14: 0}$ & $9.18^{\mathrm{c}}$ & $10.19^{\mathrm{a}}$ & $10.05^{\mathrm{ab}}$ & $9.59^{\mathrm{bc}}$ & $10.17^{\mathrm{a}}$ & 0.45 \\
\hline $\mathrm{C}_{14: 1}$ & 0.815 & 0.736 & 0.664 & 0.649 & 0.661 & 0.091 \\
\hline $\mathrm{C}_{16: 0}$ & $30.9^{\mathrm{a}}$ & $27.5^{\mathrm{b}}$ & $27.0^{\mathrm{b}}$ & $27.2^{\mathrm{b}}$ & $27.5^{\mathrm{b}}$ & 0.64 \\
\hline $\mathrm{C}_{16: 1}$ & $1.49^{\mathrm{a}}$ & $1.11^{\mathrm{b}}$ & $1.13^{\mathrm{b}}$ & $1.08^{\mathrm{b}}$ & $1.03^{\mathrm{b}}$ & 0.09 \\
\hline $\mathrm{C}_{18: 0}^{10.1}$ & $9.6_{\mathrm{c}}$ & $11.7_{\mathrm{ab}}$ & $11.0_{\mathrm{b}}$ & $11.9_{\mathrm{ab}}$ & $12.0^{\mathrm{a}}$ & 0.45 \\
\hline trans $-10 \mathrm{C}_{18: 1}$ & $0.429^{\mathrm{ab}}$ & $0.316^{\mathrm{b}}$ & $0.508^{\mathrm{a}}$ & $0.511^{\mathrm{a}}$ & $0.295^{\mathrm{b}}$ & 0.059 \\
\hline trans $-11 \mathrm{C}_{18: 1}$ & $3.23^{\mathrm{b}}$ & $3.79^{\mathrm{b}}$ & $6.58^{\mathrm{a}}$ & $6.24^{\mathrm{a}}$ & $3.97^{\mathrm{b}}$ & 0.81 \\
\hline cis $-9 \mathrm{C}_{18: 1}$ & $21.4^{\mathrm{a}}$ & $18.6^{\mathrm{b}}$ & $16.5^{\mathrm{c}}$ & $16.9^{\mathrm{c}}$ & $18.1^{\mathrm{bc}}$ & 1.0 \\
\hline cis -9, cis-12 $\mathrm{C}_{18: 2}$ & $3.36^{\mathrm{d}}$ & $3.37^{\mathrm{d}}$ & $4.03^{\mathrm{b}}$ & $4.32^{\mathrm{a}}$ & $3.75^{\mathrm{c}}$ & 0.13 \\
\hline cis -9, trans $-11 \mathrm{C}_{18: 2}$ & $0.72^{\mathrm{b}}$ & $0.82^{\mathrm{b}}$ & $1.19^{\mathrm{a}}$ & $0.78^{\mathrm{b}}$ & $0.78^{\mathrm{b}}$ & 0.086 \\
\hline trans -10, cis $-12 \mathrm{C}_{18: 2}$ & $0.039^{b c}$ & $0.025^{\mathrm{c}}$ & $0.063^{\mathrm{a}}$ & $0.055^{\mathrm{ab}}$ & $0.036^{\mathrm{bc}}$ & 0.012 \\
\hline $\mathrm{C}_{18: 3}$ & 0.334 & 0.332 & 0.316 & 0.315 & 0.330 & 0.009 \\
\hline Others & 0.827 & 0.846 & 0.821 & 0.832 & 0.850 & 0.036 \\
\hline \multicolumn{7}{|l|}{ Summation } \\
\hline SMCFA $^{3}$ & $21.7^{\mathrm{c}}$ & $24.4^{\mathrm{a}}$ & $22.8^{\mathrm{bc}}$ & $22.1^{\mathrm{c}}$ & $24.1^{\mathrm{ab}}$ & 1.3 \\
\hline Total $\mathrm{C}_{16}$ & $33.5^{\mathrm{a}}$ & $29.7^{\mathrm{b}}$ & $29.4^{\mathrm{b}}$ & $29.5^{\mathrm{b}}$ & $29.6^{\mathrm{b}}$ & 1.3 \\
\hline $\mathrm{LCFA}^{4}$ & $44.7^{\mathrm{c}}$ & $45.9^{\mathrm{c}}$ & $47.8^{\mathrm{ab}}$ & $48.6^{\mathrm{a}}$ & $46.3^{\mathrm{b}}$ & 1.6 \\
\hline Unsaturated $^{5}$ & $37.0^{\mathrm{ab}}$ & $35.6^{\mathrm{b}}$ & $38.2^{\mathrm{a}}$ & $38.0^{\mathrm{a}}$ & $35.6^{\mathrm{b}}$ & 1.7 \\
\hline trans $-\mathrm{C}_{18: 1}{ }^{6}$ & $4.85^{\mathrm{c}}$ & $6.07^{\mathrm{bc}}$ & $9.53^{\mathrm{a}}$ & $9.20^{\mathrm{a}}$ & $6.44^{\mathrm{b}}$ & 0.81 \\
\hline Total $\mathrm{C}_{18: 2}$ & $5.06^{\mathrm{c}}$ & $5.29^{\mathrm{bc}}$ & $6.48^{\mathrm{a}}$ & $6.26^{\mathrm{a}}$ & $5.6^{\mathrm{b}}$ & 0.2 \\
\hline $\mathrm{CLA}^{7}$ & $0.94^{\mathrm{b}}$ & $0.97^{\mathrm{b}}$ & $1.47^{\mathrm{a}}$ & $1.03^{\mathrm{b}}$ & $0.96^{\mathrm{b}}$ & 0.09 \\
\hline Total trans-fatty acids & $6.78^{\mathrm{c}}$ & $8.21^{\mathrm{bc}}$ & $12.20^{\mathrm{a}}$ & $11.34^{\mathrm{a}}$ & $8.54^{\mathrm{b}}$ & 0.88 \\
\hline \multicolumn{7}{|l|}{ Ratio } \\
\hline trans-10 $\mathrm{C}_{18: 1} /$ total $\mathrm{C}_{18: 1}$ & $1.53^{\mathrm{ab}}$ & $1.18^{\mathrm{b}}$ & $1.79^{\mathrm{a}}$ & $1.79^{\mathrm{a}}$ & $1.14^{\mathrm{b}}$ & 0.18 \\
\hline trans $-10 \mathrm{C}_{18: 1} /$ total trans $-\mathrm{C}_{18: 1}$ & $8.54^{\mathrm{a}}$ & $5.14^{\mathrm{b}}$ & $5.26^{\mathrm{b}}$ & $5.74^{\mathrm{b}}$ & $4.80^{\mathrm{b}}$ & 0.56 \\
\hline
\end{tabular}

a,b,c,d Means within a row with different superscripts differ $(P<0.05)$.

${ }^{1} \mathrm{CSH}=$ Whole linted cottonseed hulls, WCS $=$ whole linted cottonseed, SP = conventional small WCS pellets, LP = larger pelleted WCS, and SPD = combination of WCS products (small WCS pellets and partially delinted WCS product mixed in equal parts).

${ }^{2}$ Number of carbons:number of double bonds.

${ }^{3} \mathrm{SMCFA}=$ Short- and medium-chain fatty acids $\left(\mathrm{C}_{4}\right.$ to $\left.\mathrm{C}_{15}\right)$.

${ }^{4} \mathrm{LCFA}=$ Long-chain fatty acids $\left(\mathrm{C}_{17: 0}\right.$ to $\left.\mathrm{C}_{22: 6}\right)$.

${ }^{5}$ Sum $\mathrm{C}_{10: 1}, \mathrm{C}_{14: 1}, \mathrm{C}_{16: 1}, \mathrm{C}_{17: 1}, \mathrm{C}_{18: 1}, \mathrm{C}_{18: 2}, \mathrm{C}_{20: 1}, \mathrm{C}_{20: 2}, \mathrm{C}_{20: 3}, \mathrm{C}_{20: 4}, \mathrm{C}_{20: 5}, \mathrm{C}_{22: 5}$, and $\mathrm{C}_{22.6}$.

${ }^{6} 18: 1$ trans -4 to trans- $14 \mathrm{C}_{18: 1}$.

${ }^{7} \mathrm{CLA}=$ Conjugated linoleic acids.

${ }^{8}$ Sum trans- $\mathrm{C}_{14: 1}, \mathrm{C}_{16: 1}, \mathrm{C}_{17: 1}, \mathrm{C}_{18: 1}, \mathrm{C}_{18: 2}$, and $\mathrm{C}_{20: 1}$.

tridge, 1994; Allen, 2000) for reasons still not totally known. The higher DMI (and therefore milk production) by cows fed SPD or SPD90 seem to imply that the slowed release of fat from the partially delinted WCS component of SPD compensates for the higher levels of free oil from the SP component; in contrast, the high fat digestibility of the SP component seems to compensate for lower fat digestibility of partially delinted WCS. Thus, the SPD product seems to combine the beneficial effects of either component and dilute the negative effects of the other.

Milk fat percentage was highest for WCS and SPD (Table 7), and LP and SPD90 had milk fat-protein inver- sion. Based on trans-10 $\mathrm{C}_{18: 1}$ data (Table 6), LP would have been expected to have lower milk fat than SPD or WCS. For milk fat yield, there were no significant treatment $\times$ time interactions; averaged over the $12 \mathrm{wk}$, SPD was greater than LP, and the other two treatments had intermediate results. Apparently, DMI was the major driving factor for milk production (Figures 1 and 2). In contrast, milk fat production also is influenced by synthesis or mobilization of adipose tissue. Thus, the lower milk fat yield for LP than for SPD can be partially explained by the greater BW change for LP, diverting FA from milk to adipose tissue. For older cows, BCS was greater when cows were fed WCS or SPD, and we 
Table 7. Least squares means for lactation performance by dairy cows fed different processed whole cottonseed products in experiment $2 .^{1}$

\begin{tabular}{lccccl}
\hline & WCS & LP & SPD & SPD90 & SEM \\
\hline DMI, ${ }^{2} \mathrm{~kg} / \mathrm{d}$ & 22.0 & 22.4 & 23.3 & 23.0 & 0.6 \\
Milk production, ${ }^{3}$ kg/d & 40.1 & 39.3 & 42.9 & 42.0 & 1.0 \\
Milk fat, \% & $3.07^{\mathrm{a}}$ & $2.74^{\mathrm{b}}$ & $3.08^{\mathrm{a}}$ & $2.85^{\mathrm{b}}$ & 0.10 \\
Milk fat yield, kg/d & $1.23^{\mathrm{ab}}$ & $1.09^{\mathrm{b}}$ & $1.30^{\mathrm{a}}$ & $1.21^{\mathrm{ab}}$ & 0.06 \\
Milk protein, ${ }^{4} \%$ & & & & \\
Primiparous & $3.01^{\mathrm{b}}$ & $3.23^{\mathrm{a}}$ & $3.03^{\mathrm{b}}$ & $3.15^{\mathrm{a}}$ & 0.04 \\
Multiparous & 3.10 & 3.14 & 3.09 & 3.08 & 0.04 \\
Milk protein yield, kg/d & 1.24 & 1.26 & 1.31 & 1.31 & 0.03 \\
BCS $^{4}$ & & & & & \\
Primiparous & $3.12^{\mathrm{ab}}$ & $3.02^{\mathrm{b}}$ & $3.20^{\mathrm{a}}$ & $3.11^{\mathrm{ab}}$ & 0.07 \\
Multiparous & $2.67^{\mathrm{b}}$ & $2.88^{\mathrm{a}}$ & $2.47^{\mathrm{c}}$ & $2.77^{\mathrm{ab}}$ & 0.07 \\
BW, kg & 605 & 610 & 603 & 602 & 4 \\
BW change, kg/d & $0.42^{\mathrm{ab}}$ & $0.61^{\mathrm{a}}$ & $0.35^{\mathrm{b}}$ & $0.40^{\mathrm{b}}$ & 0.12 \\
\hline
\end{tabular}

${ }^{\mathrm{a}, \mathrm{b}, \mathrm{c}}$ Means within a row with different superscripts differ $(P<0.05)$.

${ }^{1} \mathrm{WCS}=$ Whole linted cottonseed, LP = larger pelleted WCS, SPD = combination of WCS products (small WCS pellets and partially delinted WCS product mixed in equal parts), and SPD90 = SPD at 90\% of the SPD level.

${ }^{2}$ Diet $\times$ time interaction $(P<0.05)$. See Figure 1 .

${ }^{3}$ Diet $\times$ time interaction $(P<0.05)$. See Figure 2 .

${ }^{4}$ Diet $\times$ parity interaction $(P<0.05)$.

have no explanation for this response. Cows fed SPD gained less BW than did those fed LP.

For milk protein percentage, there was a parity $\times$ treatment interaction (Table 7). There were no differences for multiparous cows, but primiparous cows had higher milk protein percentages for LP and SPD90. Dietary fat is well known to depress milk protein percentage (Doreau and Chilliard, 1997), although the mechanism has not been fully worked out. Heating during pelleting might increase RUP concentration of CS products (Arieli, 1998). The LP had a higher ERD than SP (Table 3), so RDP supply might have limited micro-

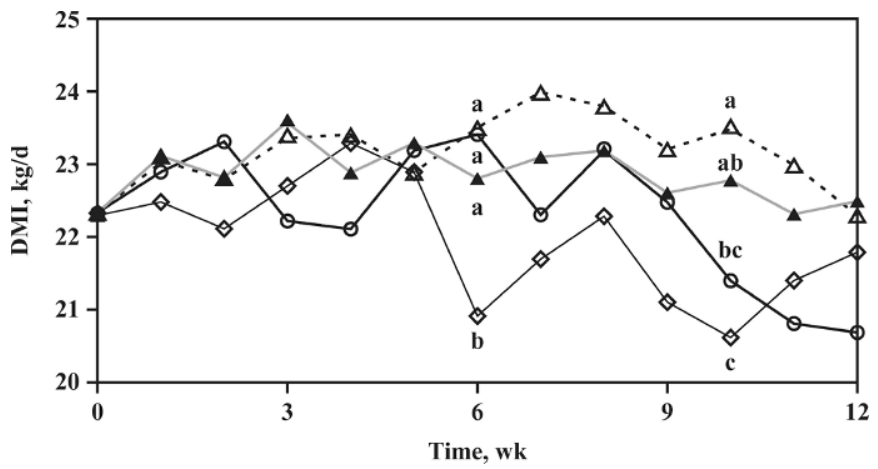

Figure 2. Least square (covariate-adjusted) means of DMI for the $12 \mathrm{wk}$ of the trial in experiment 2. WCS $=$ whole linted cottonseed $(\diamond), \mathrm{LP}=$ larger pelleted WCS $(\bigcirc), \mathrm{SPD}=$ combination of WCS products (small WCS pellets and partially delinted WCS product mixed in equal parts) $(\triangle)$, and SPD90 $=$ SPD fed at $90 \%(\Delta)$. Means in the same week with different superscripts differ $(P<0.05)$. bial protein synthesis for SPD and WCS compared with LP. Also, SPD90 had more corn and soybean meal protein to perhaps partially compensate for lower RDP of SPD. Primiparous cows are still growing, potentially making metabolizable protein more limiting than for mid-lactation multiparous cows (NRC, 2000). However, milk protein yield was not different among treatments, so differences in milk protein percentage between parities might be a result of dilution of protein by varying milk volume.

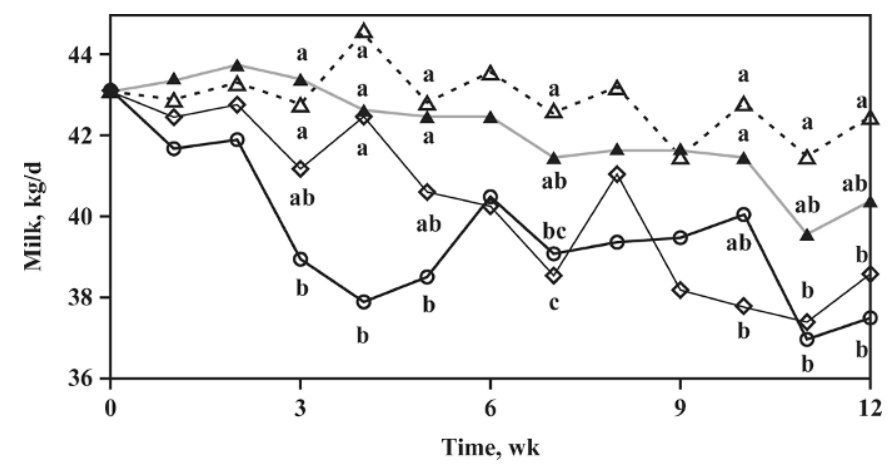

Figure 3. Least square (covariate-adjusted) means of milk production for the $12 \mathrm{wk}$ of the trial in experiment 2 . WCS = whole linted cottonseed $(\diamond), \mathrm{LP}=$ larger pelleted WCS $(\bigcirc), \mathrm{SPD}=$ combination of WCS products (small WCS pellets and partially delinted WCS product mixed in equal parts) $(\triangle)$, and SPD90 $=$ SPD fed at $90 \%(\Delta)$. Means in the same week with different superscripts differ $(P<0.05)$. 


\section{CONCLUSIONS}

The increase of pellet particle size did not appear to influence free oil metabolism in the rumen. Although having a lower FA digestibility, SPD appeared to minimize negative effects of free oil in the rumen from SP, promoting higher DMI and milk production than for WCS or LP. In this study, milk fat depression was attributed to increased biohydrogenation intermediates and not from inhibition of ruminal fiber degradation. Feeding SPD maintained comparable (SPD90) or higher (SPD) milk production over time and provided both handling and nutritional benefits compared with WCS, thus providing a potentially useful alternative for dairy feeding operations.

\section{ACKNOWLEDGMENTS}

The authors express their sincere appreciation to Andy Spring and all staff members of the Waterman research dairy farm for care and feeding of the cows.

\section{REFERENCES}

Agazzi, A., C. Bayourthe, M. C. Nicot, A. Troegeler-Meynadier, R. Moncoulon, and F. Enjalbert. 2004. In situ ruminal biohydrogenation of fatty acids from extruded soybeans: Effects of dietary adaptation and of mixing with lecithin or wheat straw. Anim. Feed Sci.Technol. 117:165-175.

Allen, M. S. 2000. Effects of diet on short-term regulation of feed intake by lactating dairy cattle. J. Dairy Sci. 83:1598-1624.

AOAC. 1990. Official Methods of Analysis. Association of Official Analytical Chemists, Arlington, VA.

Arieli, A. 1998. Whole cottonseed in dairy cattle feeding: a review. Anim. Feed Sci. Technol. 72:97-110.

Bauman, D. E., and J. M. Griinari. 2003. Nutritional regulation of milk fat synthesis. Annu. Rev. Nut. 23:203-227.

Baumgard, L. H., E. Matitashvili, B. A. Corl, D. A. Dwyer, and D. E. Bauman. 2002. Trans-10, cis-12 conjugated linoleic acid decreases lipogenic rates and expression of genes involved in milk lipid synthesis in dairy cows. J. Dairy Sci. 85:2155-2163.

Bernard, J. K., and H. E. Amos. 1985. Influence of pelleting whole cottonseed on ration digestibility and milk production and composition. J. Dairy Sci. 68:3255-3261.

Bernard, J. K., and M. C. Calhoun. 1997. Response of lactating dairy cows to mechanically processed whole cottonseed. J. Dairy Sci. 80:2062-2068.

Cant, J. P., E. J. DePeters, and R. L. Baldwin. 1990. Effect of dietary fat and postruminal casein administration on milk composition of lactating dairy cows. J. Dairy Sci. 74:219.

Castaneda-Gutierrez, E., T. R. Overton, W. R. Butler, and D. E. Bauman. 2005. Dietary supplements of two doses of calcium salts of conjugated linoleic acid during the transition period and early lactation. J. Dairy Sci. 88:1078-1089.

Chouinard, P. Y., L. Corneau, W. R. Butler, Y. Chilliard, J. K. Drackley, and D. E. Bauman. 2001. Effect of dietary lipid source on conjugated linoleic acid concentrations in milk fat. J. Dairy Sci. 84:680-690.

Doreau, M., and Y. Chilliard. 1997. Digestion and metabolism of dietary fat in farm animals. Br. J. Nut. 78(Suppl. 1):S15-S35.

Enjalbert, F., P. Eynard, M. C. Nicot, A. Troegeler-Meynadier, and C. Bayourthe. 2003. In vitro versus in situ ruminal biohydrogenation of unsaturated fatty acids from a raw or extruded mixture of ground canola seed/canola meal. J. Dairy Sci. 86:351-359.
Firkins, J. L., and M. L. Eastridge. 1994. Assessment of the effects of iodine value on fatty acid digestibility, feed intake, and milk production. J. Dairy Sci. 77:2357-2366.

Gonthier, C., A. F. Mustafa, R. Berthiaume, H. V. Petit, R. Martineau, and D. R. Ouellet. 2004. Effects of feeding micronized and extruded flaxseed on ruminal fermentation and nutrient utilization by dairy cows. J. Dairy Sci. 87:1854-1863.

Harfoot, C. G., and G. Hazlewood. 1997. Lipid metabolism in the rumen. Page 382 in The Rumen Microbial Ecosystem. P. N. Hobson and C. S. Stewart, ed. Chapman and Hall, New York, NY.

Harfoot, C. G., R. C. Noble, and J. H. Moore. 1973. Factors influencing the extent of biohydrogenation of linoleic acid by rumen microorganisms in vitro. J. Sci. Food Agric. 24:961-970.

Harvatine, D. I., J. L. Firkins, and M. L. Eastridge. 2002a. Whole linted cottonseed as a foragae substitute fed with ground or steamflaked corn: Digestibility and performance. J. Dairy Sci. 85:1976-1987.

Harvatine, D. I., J. E. Winkler, M. Devant-Guille, J. L. Firkins, N. R. St-Pierre, B. S. Oldick, and M. L. Eastridge. 2002b. Whole linted cottonseed as a forage substitute: Fiber effectiveness and digestion kinetics. J. Dairy Sci. 85:1988-1999.

Kramer, J. K., V. Fellner, M. E. Dugan, F. D. Sauer, M. M. Mossoba, and M. P. Yurawecz. 1997. Evaluating acid and base catalysts in the methylation of milk and rumen fatty acids with special emphasis on conjugated dienes and total trans fatty acids. Lipids 32:1219-1228.

Leonardi, C., F. Giannico, and L. E. Armentano. 2005. Effect of water addition on selective consumption (sorting) of dry diets by dairy cattle. J. Dairy Sci. 88:1043-1049.

Lima, M. L. M., J. L. Firkins, J. T. Sylvester, S. K. Karnati, and W. Mattos. 2003. Physical effectiveness of whole cottonseed as affected by lint and particle size. J. Dairy Sci. 86(Suppl. 1):64. (Abstr.)

Meyer, M. J., J. E. Shirley, E. C. Titgemeyer, A. F. Park, and M. J. VanBaale. 2001. Effect of mechanical processing and fat removal on the nutritive value of cottonseed for lactating dairy cows. J. Dairy Sci. 84:2503-2514.

Moreira, V. R., L. D. Satter, and B. Harding. 2004. Comparison of conventional linted cottonseed and mechanically delinted cottonseed in diets for dairy cows. J. Dairy Sci. 87:131-138.

Mosley, E. E., G. L. Powell, M. B. Riley, and T. C. Jenkins. 2002. Microbial biohydrogenation of oleic acid to trans isomers in vitro. J. Lipid Res. 43:290-296.

NRC. 2001. Nutrient Requirements of Dairy Cattle. 7th rev. ed. Washington, DC.

Ohajuruka, O. A., Z. G., Wu, and D. L. Palmquist. 1991. Ruminal metabolism, fiber, and protein digestion by lactating cows fed calcium soap or animal-vegetable fat. J. Dairy Sci. 74:2601-2609.

Oldick, B. S., and J. L. Firkins. 2000. Effects of degree of fat saturation on fiber digestion and microbial protein synthesis when diets are fed twelve times daily. J. Anim. Sci. 78:2412-2420.

Onetti, S. G., R. D. Shaver, M. A. McGuire, and R. R. Grummer. 2001. Effect of type and level of dietary fat on rumen fermentation and performance of dairy cows fed corn silage-based diets. J. Dairy Sci. 84:2751-2759.

Palmquist, D. L., and T. C. Jenkins. 2003. Challenges with fats and fatty acid methods. J. Anim. Sci. 81:3250-3254.

Perrier, R., B. Michalet-Doreau, D. Bauchart, and M. Doreau. 1992. Assessment of an in-situ technique to estimate the degradation of lipids in the rumen. J. Sci. Food Agric. 59:449-455.

Peterson, D. G., J. A. Kelsey, and D. E. Bauman. 2002. Analysis of variation in cis-9, trans-11 conjugated linoleic acid (CLA) in milk fat of dairy cows. J. Dairy Sci. 85:2164-2172.

Peterson, D. G., E. A. Matitashvili, and D. E. Bauman. 2003. Dietinduced milk fat depression in dairy cows results in increased trans-10, cis-12 CLA in milk fat and coordinate suppression of mRNA abundance for mammary enzymes involved in milk fat synthesis. J. Nutr. 133:3098-3102.

Piperova, L. S., U. Moallem, B. B. Teter, J. Sampugna, M. P. Yurawecz, K. M. Morehouse, D. Luchini, and R. A. Erdman. 2004. Changes in milk fat in response to dietary supplementation with 
calcium salts of trans-18:1 or conjugated linoleic fatty acids in lactating dairy cows. J. Dairy Sci. 87:3836-3844.

Slater, A. L., M. L. Eastridge, J. L. Firkins, and L. J. Bidinger. 2000. Effects of starch source and level of forage neutral detergent fiber on performance by dairy cows. J. Dairy Sci. 83:313-321.

Solomon, R., G. Adin, S. J. Mabjeesh, M. Nikbachat, E. Yosef, D. Ben-Ghedalia, and J. Miron. 2005. Digestibility in lactating cows of diets containing whole Pima treated with sodium hydroxide versus Akala or Pima cottonseed. J. Dairy Sci. 88:1745-1751.

Sullivan, H. M., J. K. Bernard, and H. E. Amos. 2005. Ruminal fermentation and amino acid flow in Holstein steers fed whole cottonseed with elevated concentrations of free fatty acids in the oil. J. Dairy Sci. 88:690-697.

Sullivan, J. L., J. T. Huber, and J. M. Harper. 1993. Performance of dairy cows fed short staple, Pima, and cracked Pima cottonseed and feed characteristics. J. Dairy Sci. 76:3555-3561.

Williams, C. H., D. J. David, and O. Iismaa. 1962. The determination of chromic oxide in feces samples by atomic absorption spectrophotometry. J. Agric. Sci. 59:381-385.

Wu, Z., and D. L. Palmquist. 1991. Synthesis and biohydrogenation of fatty acids by ruminal microorganisms in vitro. J. Dairy Sci. 74:3035-3046. 